\title{
ANTIPYRETIC ACTIVITY AND ACUTE TOXICITY OF PHOSPHOROUS CONTAINING SALICYLATES
}

\author{
A. K. Brel ${ }^{1}$, S. V. Lisina ${ }^{1}$ \\ ${ }^{1}$ Department of Chemistry, Pharmaceutical Faculty, Volgograd State Medical University, 1, Pavshikh Bortsov \\ Sq., Volgograd, 400131, Russian Federation
}

\begin{abstract}
New phosphorous-containing salicylates and two allyl salicylates with pharmacological potential, derived from salicylic acid, have been synthesized. Their chemical structure has been established by spectral analyses (mass spectra and 1H-NMR). The salicylates presented low toxicity, also showing a remarkable antipyretic activity, greater than that of acetylsalicylic acid (aspirin). Partition coefficient (log P), and dissociation constant $(\mathrm{pKa})$ were calculated by the use of ACDLabs system software. The obtained values were correlated with experimental data of activity.
\end{abstract}

Keywords: salicylates, antipyretic activity, acute toxicity.

\section{INTRODUCTION}

The interest in salicylic acid derivatives is due to their numerous pharmacological applications. Literature data offer various examples of salicylates with biological activity, including local anaesthetic, anti-inflammatory, antipyretic, analgesic, and antibacterial effects [1]. Salicylate toxicity and poisoning are rare in recommended doses, however, salicylate side effects are prominent problem in developing countries where they are used as antipyretic. Meanwhile, there are development and introduction of new antipyretic agents that compete with aspirin. This has made chemists to search for a better tolerable drug which are devoid of toxic and side effects of aspirin has been shown in the central nervous system, respiratory, gastro-intestinal tract, hepatic, metabolic and coagulation systems of the body [2]. This work is the stage in evaluating the various biological activities produced by wide range of oxybenzoic acids derivatives synthesized in our laboratory. In some therapeutic classes, a phosphonic acid is a bioisostere for a carboxylic acid.In the World Drug Index there are many compounds, primarily aliphatic, which contain a phosphonic acid group [3].This communication therefore describes the synthesis of salicylates such as allyl 2-hydroxybenzoate, allyl 2acetoxybenzoate, dimethyl $\beta($ Osalicyloyl)ethylphosp honate, diethyl $\beta$ (Osalicyloyl)ethylphosphonate, diiso propyl- $\beta$-(O-salicyloyl) ethylphosphonate, and their effects on temperature (pyrexia) and toxicity.The lipophilicity of a substance is one of the parameters which influences its biological activity and is wellknown prime physiochemical descriptor to QSAR study [4]. Lipophilicity, expressed as the logarithmic value of the octanol/water partition coefficient $(\log \mathrm{P})$, is a fundamental parameter that models the biological partition behavior of drug molecules. For example, drug absorption and $\log \mathrm{P}$ are directly related because of passive diffusion across the cell membrane. If the $\log \mathrm{P}$ value is below 0 or above 5 , drug candidates usually have intestinal and central nervous system (CNS) permeability problems or low solubility and poor oral bioavailability [5]. The aim of this study was to synthesize new phosphorus-containing salicylates and determine the relationship between lipophilicity and antipyretic activity of new salicylates of which some have shown anti fever activities higher than aspirin.

\section{MATERIALS AND METHODS}

Mass spectra were performed by Zelinsky Institute of Organic Compounds (Russia, Moscow) and were made on ESI-TOF spectrometer. 1H NMR $(300 \mathrm{MHz})$ spectra were recorded in DMSO-d on Varian Mat 111. Chemical shifts are reported in parts per million downfield from internal reference tetramethyl silane (TMS). The values of elemental analyses were found to be within $\pm 0.4 \%$ of the theoretical ones unless otherwise indicated. The other chemicals were of analytical grade and were used as purchased (SigmaAldrich, Fluka).

\section{Chemistry}

General procedure for synthesis of allyl salicylate (I-II).

Salicylic (2-hydroxybenzoic) acid (SA) or acetylsalicylic (2-acetoxybenzoic) acid (ASA) (27.8 $\mathrm{mmol})$, anhydrous potassium carbonate $(14.5 \mathrm{mmol})$ were dissolved in N,N-dimethylformamide $(20 \mathrm{ml})$ 
at $60-65^{\circ} \mathrm{C}$. To the solution allyl bromide $(28.1$ mmol) was added gently. The reaction mixture was left for reflux for $1.5 \mathrm{~h}$, and then, after cooling, washed with water and extracted with ether. The product was distilled under reduced pressure and collected allyl salicylate (allyl acetylsalicylate) as a colorless liquid.

General procedure for synthesis of dialkyl- $\beta-(\mathrm{O}-$ salicyloyl)ethylphosphonate (III-V).

Benzene (25 ml), SA (36 mmol), dialkyl (2hydroxyethyl)phosphonate $(39.6 \mathrm{mmol})$ and $\mathrm{p}$ -
TsOH (2.52 mmol) were placed into a $100 \mathrm{ml}$ round-bottomed flask provided with Dean-Stark receiver. The reaction was left for reflux for 8 hours. After cooling, the reaction mixture was poured into excess water, separated the benzene layer, washed with saturated sodium bicarbonate, dried with anhydrous magnesium sulphate, filtered, and evaporated. The product was distilled under reduced pressure and collected dialkyl- $\beta-(\mathrm{O}-$ salicyloyl)ethylphosphonate as a colorless liquid soluble in organic solvents and insoluble in water.

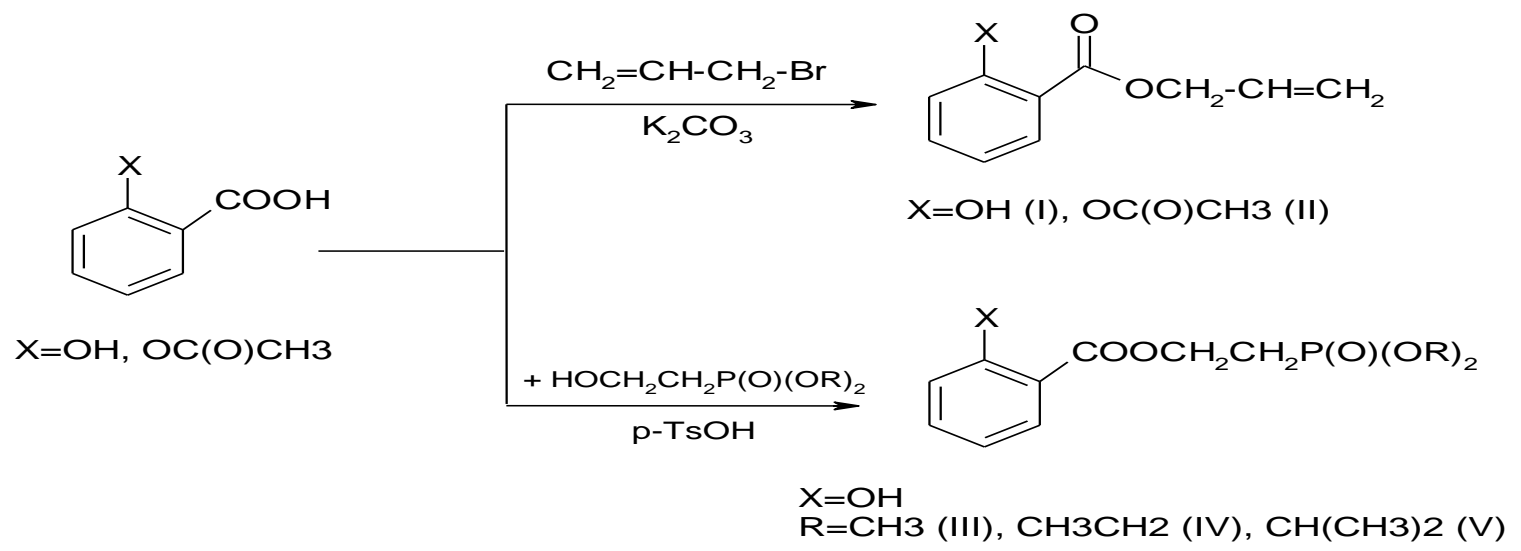

Figure 1. Outline for the synthesis of compounds I-V

Table 1. New phosphorous-containing salicylates (III-V)

\begin{tabular}{|c|c|c|c|c|c|c|c|c|}
\hline Compd. & $\begin{array}{l}\text { Yield } \\
(\%)\end{array}$ & $\begin{array}{l}\mathrm{Bp}\left({ }^{0} \mathrm{C},\right. \\
3-5 \\
\mathrm{~mm} \\
\mathrm{Hg})\end{array}$ & MW & $\mathrm{C}(\%)$ & $\mathrm{H}(\%)$ & $\mathrm{O}(\%)$ & $\mathrm{P}(\%)$ & Spectral analyses \\
\hline III & 67,8 & $\begin{array}{c}143- \\
147\end{array}$ & 274.20 & $\begin{array}{c}48,17 \\
(48.18)\end{array}$ & $\begin{array}{c}35,05 \\
(35.01)\end{array}$ & $\begin{array}{c}5,47 \\
(5.51)\end{array}$ & $\begin{array}{c}11,31 \\
(11.30)\end{array}$ & $\begin{array}{c}\text { 1H NMR: } 6.92-8.04 \mathrm{~m}(4 \mathrm{H}, \\
\text { phenylene }), 4.34-4.47 \mathrm{~m}(2 \mathrm{H}, \mathrm{O}- \\
\left.\mathrm{CH}_{2}\right), 2.25-2.46 \mathrm{~m}(6 \mathrm{~Hz}, 2 \mathrm{H}, \mathrm{P}- \\
\left.\mathrm{CH}_{2}\right), 3.64-3.74 \mathrm{~m}(6 \mathrm{H}, \mathrm{O}-\mathrm{CH} 3) \\
11.02 \mathrm{~s}(1 \mathrm{H}, \mathrm{Ar}-\mathrm{OH}) \\
\mathrm{M}+274\end{array}$ \\
\hline IV & 60,2 & $\begin{array}{c}178- \\
182\end{array}$ & 302.26 & $\begin{array}{c}51,66 \\
(51.66)\end{array}$ & $\begin{array}{c}31,79 \\
(31.76)\end{array}$ & $\begin{array}{c}6,29 \\
(6.34)\end{array}$ & $\begin{array}{c}10,26 \\
10.25)\end{array}$ & $\begin{array}{c}\text { 6,34-7,30 m (4H, phenylene), 3,89- } \\
4,29 \mathrm{~m}(2 \mathrm{H}, \mathrm{O}-\mathrm{CH} 2), 1,52-1,64 \mathrm{~m} \\
(4 \mathrm{H}, \mathrm{CH} 2), 0,81-1,30 \mathrm{~m}(3 \mathrm{H}, \mathrm{CH} 3) \\
10,82 \mathrm{~s}(1 \mathrm{H}, \mathrm{Ar}-\mathrm{OH}) \\
\mathrm{M}+302\end{array}$ \\
\hline $\mathrm{V}$ & 53,3 & $\begin{array}{c}180- \\
183\end{array}$ & 344.34 & $\begin{array}{c}54,55 \\
(54.54)\end{array}$ & $\begin{array}{c}29,09 \\
(29.06)\end{array}$ & $\begin{array}{c}6,97 \\
(7.02)\end{array}$ & $\begin{array}{c}9,39 \\
(9.38)\end{array}$ & $\begin{array}{c}\text { 1H NMR: 6.84-7.80 m }(4 \mathrm{H}, \\
\text { phenylene }), 4.42-4.71 \mathrm{~m}(7 \mathrm{~Hz}, 2 \mathrm{H}, \\
\mathrm{O}-\mathrm{CH} 2), 4.43-4.61 \mathrm{~m}(2 \mathrm{H}, \mathrm{P}-\mathrm{CH} 2) \\
3.07-3.76 \mathrm{~m}(2 \mathrm{H}, \mathrm{O}-\mathrm{CH}), 0.88-1.46 \\
\mathrm{~m}(12 \mathrm{H}, \mathrm{CH} 3), 10.96 \mathrm{~s}(1 \mathrm{H}, \mathrm{Ar}-\mathrm{OH}) \\
\mathrm{M}+344\end{array}$ \\
\hline
\end{tabular}




\section{Pharmacology}

\section{Anti-pyretic activity in rats}

The antipyretic activity was evaluated for the prepared compounds by using the yeast-induced hyperpyrexia method [6]. We used rats of either sex, weighted $170.85 \pm 9.47 \mathrm{~g}$, which were divided into eight groups. Rats were given s.c. $20 \mathrm{ml} / \mathrm{kg}$ of $20 \%$ aqueous suspension of sterilized brewer's yeast powder. After $18 \mathrm{~h}$, animals showing an increase of rectal temperature $>0.5{ }^{0} \mathrm{C}$ were selected. Control group received olive oil; treated groups received $50 \mathrm{mg} / \mathrm{kg}$ of SA, ASA (aspirin) and compounds I to $\mathbf{V}$, respectively. Rectal temperature was determined by thermal-probe (Omron thermometer) at 1, 2, 3 and $4 \mathrm{~h}$ after administration. The idea behind the study was to compare the antipyretic effect obtained with salicylic acid and aspirin and the synthesized compounds in oil. Student's t-test was employed for statistical analysis of the data. A probability value less than 0.05 was considered statistically significant. Values in the text and table 2 are represented as mean \pm SEM.

Table 2. Antipyretic activity of synthesized salicylates compared to reference antipyretic drugs salicylic acid (SA) and acetylsalicylic acid (ASA)

\begin{tabular}{|c|c|c|c|c|c|c|}
\hline \multirow{2}{*}{ 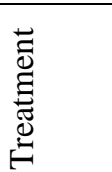 } & \multicolumn{2}{|c|}{$\begin{array}{l}\text { Body temperature before antipyretic treatment } \\
\left({ }^{\circ} \mathrm{C}\right)^{*}\end{array}$} & \multicolumn{4}{|c|}{ After drug administration $\left({ }^{\circ} \mathrm{C}\right) *$} \\
\hline & Initial & $18 \mathrm{~h}$ after pyrexia induction & $1 \mathrm{~h}$ & $2 \mathrm{~h}$ & $3 \mathrm{~h}$ & $4 \mathrm{~h}$ \\
\hline SA & $38.30 \pm 0.16$ & $39.10 \pm 0.16$ & $38.30 \pm 0.28$ & $38.66 \pm 1.24$ & $38.70 \pm 1.23$ & $38.74 \pm 0.20$ \\
\hline ASA & $38.32 \pm 0.12$ & $39.07 \pm 0.30$ & $38.28 \pm 0.20$ & $38.42 \pm 0.07$ & $38.40 \pm 0.09$ & $38.23 \pm 0.07$ \\
\hline I & $38.15 \pm 0.30$ & $38.78 \pm 0.39$ & $38.50 \pm 0.33$ & $38.43 \pm 0.57$ & $38.52 \pm 0.29$ & $38.38 \pm 0.24$ \\
\hline II & $38.12 \pm 0.22$ & $39.17 \pm 0.07$ & $38.37 \pm 0.35$ & $37.32 \pm 0.55$ & $37.43 \pm 0.54$ & $37.63 \pm 0.59$ \\
\hline III & $38.27 \pm 0.02$ & $39.43 \pm 0.08$ & $37.96 \pm 1.27$ & $38.16 \pm 1.33$ & $38.40 \pm 1.36$ & $38.50 \pm 1.39$ \\
\hline IV & $38.37 \pm 0.30$ & $39.77 \pm 0.15$ & $38.90 \pm 0.37$ & $38.80 \pm 0.28$ & $38.90 \pm 0.26$ & $39.13 \pm 0.32$ \\
\hline $\mathrm{V}$ & $37.10 \pm 0.21$ & $38.43 \pm 0.07$ & $37.40 \pm 0.26$ & $37.53 \pm 0.22$ & $37.60 \pm 0.14$ & $38.03 \pm 0.15$ \\
\hline Control & $38.31 \pm 0.16$ & $39.10 \pm 0.17$ & $39.13 \pm 0.09$ & $39.15 \pm 0.10$ & $39.30 \pm 0.16$ & $38.95 \pm 0.14$ \\
\hline
\end{tabular}

*Values represent the rectal temperature mean \pm S.E.M. *p $<0.05$

\section{Acute toxicity of synthesized compounds, SA and ASA}

All of the synthesized compounds, SA and ASA were further evaluated for their approximate acute lethal dose $\mathrm{LD}_{50}$ in male mice using a literature method [7]. Albino mice of either sex weighing $22.83 \pm 0.46 \mathrm{~g}$ were grouped into 12 groups of six animals each, starved for $24 \mathrm{~h}$ with water ad libitum prior to test. On the day of the experiment animals were administered with different compounds to different groups in an increasing dose of 200, 500, $1000,1500,2000,2500$ and $3000 \mathrm{mg} / \mathrm{kg}$ body weight orally (table 3 ). The animals were then observed continuously for $3 \mathrm{~h}$ for general behavioral, neurological, autonomic profiles and then every $30 \mathrm{~min}$ for next $3 \mathrm{~h}$ and finally for next $24 \mathrm{~h}$ or till death and daily thereafter for a total of 15 days. Body weights were recorded prior to fasting, immediately preceding dosing and at 15 days. All mice which died on study were subjected to gross necropsy examination as were all survivors at the end of the 15-day observation period. All surviving mice exhibited normal body weight gains during the 15-day observation period. All major organs were examined. No treatment-related gross pathological changes were found in the organs of the mice at the dose levels tested. The $\mathrm{LD}_{50}$ of studied compounds in mice was calculated by the Litchfield-Wilcoxson method. 
Table 3. Acute toxicity of synthesized salicylates compared to SA and ASA

\begin{tabular}{lll}
\hline Compound & $\begin{array}{l}\mathrm{LD}_{50}, \\
\mathrm{mg} / \mathrm{kg} \text { body }\end{array}$ & Therapeutic index \\
\hline SA & 462.21 & 9.24 \\
\hline ASA (aspirin) & 245.69 & 4.90 \\
\hline II & 2679.29 & 53.58 \\
\hline III & 2296.82 & 45.94 \\
\hline IV & 2016.23 & 40.32 \\
\hline V & 1990.32 & 39.81 \\
\hline
\end{tabular}

\section{RESULTS AND DISCUSSION}

The results of the antipyretic activity of the compounds are presented in Table 2. Administration of the yeast to the rats produced significant increase in rectal temperature $18 \mathrm{~h}$ after yeast injection. Group treated with I (allyl salicylate) showed an anti-pyretic effect of $0.4{ }^{\circ} \mathrm{C}$, the leading groups were group II (allyl acetylsalicylate) - anti-pyretic effect up to $1.8{ }^{0} \mathrm{C}$, group III (dimethyl- $\beta-(\mathrm{O}-$ salicyloyl)ethylphosphonate) - up to $1.4{ }^{\circ} \mathrm{C}$, group IV (diethyl- $\beta-(\mathrm{O}$-salicyloyl)ethylphosphonate $)$ - up to $0.9{ }^{0} \mathrm{C}$, group $\mathrm{V}$ (diisopropyl- $\beta-(\mathrm{O}-$ salicyloyl)ethylphosphonate) - up to $1.0{ }^{0} \mathrm{C}$. Treatment with aspirin and synthesized salicylates showed an antipyretic effect within 5 hours. Salicylates II - V demonstrated the high activity, being preferred for further laboratory toxicity screening. However, allyl acetylsalicylate (II) and dimethyl- $\beta-(\mathrm{O}$-salicyloyl)ethylphosphonate

(III) manifested a remarkable antipyretic activity much higher than that of acetylsalicylic acid. Toxicological data showed that allyl acetylsalicylate and new phosphorous-containing salicylates reduced toxicity.

The term "therapeutic index" refers to the therapeutic index of a drug defined as the ratio of the compound's $50 \%$ toxic concentration $\left(\mathrm{LD}_{50}\right)$ to the compound's 50\% effective therapeutic concentration $\left(\mathrm{ED}_{50}\right)$. In the study, dosage of 50 $\mathrm{mg} / \mathrm{kg}$ was used as effective $\left(E_{50}\right)$ for all studied salicylates. All synthesized salicylates presented about ten times lower toxicity and higher therapeutic index levels than aspirin (table 3).

The allyl fragment in aspirin and phosphonate residue in salicylic acid molecule are significant fractions of compounds that would be deemed to have such satisfactory anti fever activity through oral bioavailability

Table 4. $\log \mathrm{P}, \log \mathrm{D} 7.4$ and $\mathrm{pKa}$ values for salicylates I-V

\begin{tabular}{cccc}
\hline Compound & LogP & $\mathrm{pKa}$ & $\operatorname{LogD7.4}$ \\
\hline SA & 2.37 & 3.0 & -0.78 \\
\hline ASA & 1.39 & 3.5 & -1.69 \\
\hline I & 3.25 & 8.1 & 3.17 \\
\hline II & 2.32 & - & 2.32 \\
\hline III & 1.96 & 8.0 & 1.87 \\
\hline IV & 2.77 & 8.0 & 2.68 \\
\hline V & 3.52 & 8.0 & 3.43
\end{tabular}


The estimated $\log \mathrm{P}$ 's of the compounds match the requirement of drug-like criteria $\left(0<\log P_{\text {oct }}<5\right)$ [8]. As shown in table 4, the $\log P$ values for the phosphorus-containing salicylates are 1.96 to 3.52 $(\log$ D7.4 values are 1.87 to 3.43$)$, and for allyl salicylates, 2.32 to $3.25(\log 7.4$ are 2.32 to 3.17$)$. In general, replacing a carboxylic $\mathrm{OH}$ group with phosphorus-containing residue or allyl radical on SA or ASA molecules can be expected to increase the $\log \mathrm{P}$ by at least $0.5 \log \mathrm{P}$ unit. The $\mathrm{pKa}$ values of phosphonates are 8 , and for the allyl salicylates are 7 to 8.1. All studied compounds are much less acidic compounds than SA or ASA, which may be helpful in active transport. Analysis of the relationship between $\log \mathrm{P}$ values and the antipyretic activity showed that the most active anti pyretic compounds had $\log \mathrm{P}$ values about 2 (II and III), but the potency began to decrease if the value of $\log \mathrm{P}$ was too high, which decreased the rate of absorption of the compound. In the series above, anti-pyretic activity dropped off for isopropylsubstituted phosphonate (V) and allyl salicylate (I) with $\log \mathrm{P}>3.0$.

\section{CONCLUSIONS}

From above study it may be concluded that all synthesized salicylates have shown antipyretic activity higher to that of aspirin. The present study of new compounds containing a phosphoric residue indicates that they can and do play a role in drug design. The obtained values of $\mathrm{pKa}$ and $\log \mathrm{P}$ were correlated with experimental data of activity.

\section{ACKNOWLEDGMENTS}

The authors wish to express their appreciation to professor A.A. Spasov of Volgograd State Medical University, Volgograd, Russia for his cooperation in the study of pharmacological activity.

\section{REFERENCES}

1. Avdeef A. (2001). Physicochemical profiling (solubility, permeability and charge state). Curr. Top. Med. Chem. 1: 277-351.
2. Brel A., Lisina S. (2012). Synthesis and Antiplatelet Activity of Alkyl Salicylates Sodium Salts. J. Mater. Sci. Eng. 2 (9): 624-628.

3. Franz R. G. (2001). Comparisons of $\mathrm{pKa}$ and Log P Values of Some Carboxylic and Phosphonic Acids: Synthesis and Measurement. AAPS PharmSci. 3 (2): 113.

4. Goldfrank L. R., Bresnitzn E. A., Hartnett L. (1990). Salicylates. In: Goldfrank's Toxicologic Emergencies (ed. Goldfrank L.R). East Norwalk, CT, Appleton \& Lange: pp. 261-270.

5. Lewgowd W., Staczak A., Chocki Z., Rzeszowska-Modzelewska K. (2007) Determination of lipophilicity and $\mathrm{pKa}$ measurement of some 4-imino-1,4dihydrocinnoline-3-carboxylic acid and 4oxo-1,4-dihydrocinnoline-3-carboxylic acid derivatives isosteric analogues of quinolones. Acta Pol. Pharm. Drug Res. 64 (3): $195-200$.

6. Margabandu R., Subramani K. (2010). Experimental and Theoretical Study on Lipophilicity and Antibacterial Activity of Biphenylamine Derivatives. Int. J. Chem. Tech. Res. 2 (3): 1501-1506.

7. Roszkowski A. P., Rooks W., Tomolonis A. J., Miller L. M. (1971). Antiinflammatory and analgetic properties of d2-(6'methoxy-2'-naphthyl)propionic acid (naproxen). J. Pharmacol. Exp. Ther. 179: 114-123.

8. Rostoma S. A. F., El-Ashmawy I. M., Abd El Razikc H. A., Badr M. H., Ashour H. M. A. (2009). Design and synthesis of some thiazolyl and thiadiazolyl derivatives of antipyrine as potential non-acidic antiinflammatory, analgesic and antimicrobial agents. Bioorg. Med. Chem. 217: 882-895 